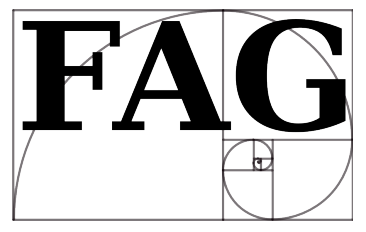

Filozoficzne Aspekty Genezy — 2013, t. 10

http://www.nauka-a-religia.uz.zgora.pl/images/FAG/2013.t.10/art.09.pdf

\title{
Gary Emberger
}

\section{Teologiczne i naukowe wyjaśnienia pochodzenia i celu zła naturalnego}

Zdarzenia w rodzaju trzęsień ziemi $i$ wyniszczajacych chorób często uważane sa za coś złego i sktaniaja do zadawania kłopotliwych pytań o Boża dobroć. Chociaż nauka nie uznaje takich zdarzeń za złe, to jednak dostarcza pewnych wskazówek na temat ich pochodzenia. Teodycea podejmuje próbę teologicznego wyjaśnienia pochodzenia zła oraz celu, w jakim Bóg pozwala mu istnieć. Pytanie, czy ewolucja może być jednym z Boskich mechanizmów stwórczych, uzyskuje inna odpowiedź w świetle założeń teodycei augustiańskiej, a inna w ramach teodycei ireneuszowej. Uznając, że każda prawda jest prawdą Bożą, chrześcijanie staraja się stworzyć poglad na świat, który łaczyłby naukowe i teologiczne spojrzenie na prowadzace do cierpienia zdarzenia przyrodnicze.

Chrześcijanie najczęściej mają ambiwalentny stosunek do świata przyrody. Istnieją w nim cierpienie, skrajny ból i śmierć, ale wierzymy też, że został stworzony przez Boga, który uznał go za dobry i rozciągnął nad nim swoją władzę. Czytamy, że Bóg zapewnia pożywienie lwom i krukom (Hi 38:39, 41) oraz ptakom podniebnym (Mt 6:26), że nawet śmierć wróbli nie umknie Jego uwadze

* Gary EMberger, „Theological and Scientific Explanations for the Origin and Purpose of Natural Evil”, Perspectives on Science and Christian Faith 1994, vol. 46, no. 3, s. 150-158, http:// www.asa3.org/ASA/PSCF/1994/PSCF9-94Emberger.html (23.02.2013). Za zgodą Autora i Redakcji z języka angielskiego przełożyli: Małgorzata GAZDA, Artur Gierzkiewicz, Paweł JAkUBowski, Radosław Plato i Dariusz Sagan. Przekładu dokonali studenci filozofii na Uniwersytecie Zielonogórskim w ramach translatorium z języka angielskiego, prowadzonego przez dra Dariusza Sagana. 
(Łk 12:6), że igra $\mathrm{z}$ Lewiatanem (Ps 104:26), nadaje piękno kwiatom (Łk 12:27), a całe stworzenie oddaje mu chwałę (Ps 148). Złożoność, piękno i dostrzegalny projekt naszego świata przedstawione są w Biblii jako wyraźne świadectwa „niewidzialnych przymiotów” Boga — „wiekuistej Jego potęgi oraz bóstwa" (Rz 1:20 [BT]). Co jednak ze starzeniem się i śmiercią? Co z chorobami, pasożytami, drapieżnikami, suszami, trzęsieniami ziemi, wadami wrodzonymi, powodziami, ślepotą, upośledzeniem umysłowym i wypadkami? Czy jest to część stworzenia, które Bóg nazwał dobrym? Czy raczej wielu ludzi, nie tylko chrześcijan, uznaje te zjawiska za przejawy zła?

Podejmowane przez chrześcijan próby wyjaśnienia pochodzenia oraz celu cierpienia, bólu i śmierci wiążą się z poważnym problemem teologicznym: jak wszechmogący, wszechwiedzący, kochający Bóg mógł stworzyć świat, w którym istnieje zło? John Hick przedstawia ten dylemat następująco: „Jeśli Bóg jest absolutnie dobry, to musi chcieć położyć kres wszelkiemu złu; jeśli jest bezgranicznie potężny, to musi być w stanie je unicestwić; jednak zło istnieje, zatem albo Bóg nie jest absolutnie dobry, albo nie jest bezgranicznie potężny". ${ }^{1}$ To właśnie ze względu na ten problem wielu ludzi, którzy nie są chrześcijanami, nie potrafi uwierzyć w Boga, zaś wśród chrześcijan często przyczynia się on do osłabienia wiary. Trudno nam pogodzić się z obecnością zła na świecie stworzonym przez wszechmocnego Boga miłości.

\section{Chrześcijańskie wyjaśnienia pochodzenia i celu zla naturalnego}

Próby rozwiązania tego dylematu muszą, jak twierdzi Clive Staples Lewis,

ustrzec nas przed dwiema przedchrześcijańskimi teoriami na temat początków zła. Pierwszą z nich jest monizm, wedle którego Bóg działa bezstronnie, jest bowiem „poza dobrem i złem” — to tylko my klasyfikujemy skutki Jego działań jako „dobre” lub „złe”. Druga teoria to dualizm, który twierdzi, że Bóg jest sprawcą dobra, natomiast zło stwarza pewna inna moc, równa Mu i niezależna od Niego. ${ }^{2}$

\footnotetext{
${ }^{1}$ John Hick, Evil and the God of Love, Harper \& Row, New York 1966, s. 5.

${ }^{2}$ Clive Staples Lewis, Problem cierpienia, przeł. Andrzej Wojtasik, Wydawnictwo Esprit, Kraków 2010, s. 83.
} 
W Biblii znajdujemy niezgodne $\mathrm{z}$ tymi koncepcjami twierdzenia, że zło jest rzeczywiste, wdarło się do Bożego świata przez grzech i pewnego dnia zostanie unicestwione. Ponadto według Biblii tylko Bóg jest wieczny i całkowicie suwerenny. Zło jest konsekwencją nadużycia wolnej woli i trwa w istnieniu wyłącznie dzięki przyzwoleniu Boga i dla Jego celów.

Chrześcijańskie wyjaśnienia pochodzenia i celu cierpienia, bólu i śmierci należą do działu teologii zwanego teodyceą. Teodycea to „filozoficzna próba uzasadnienia relacji Boga do ludzkości i zrozumienia, dlaczego Bóg pozwala na istnienie zła". ${ }^{3}$ Większość teodycei dzieli zło na moralne i naturalne. Zło moralne to takie, którego źródłem jest człowiek: kłamstwa, kradzieże, morderstwa, chciwość czy egoizm. Zło naturalne to zło, którego przyczyny są niezależne od czynów człowieka: huragany, tężec, susze, wady wrodzone, trzęsienia ziemi, skrajne cierpienie zwierząt i ludzi. Wszelkie próby zdefiniowania i klasyfikacji zła obarczone są pewnymi problemami. Istnieją wątpliwości co do tego, co naprawdę jest złe. Na przykład Robert Clark twierdzi, że „ludzkie zmagania z przyrodą z reguły nie są walką z czymś złym, lecz próbą utrzymania na właściwym miejscu tego, co potencjalnie dobre i użyteczne". ${ }^{4}$ Clark i Peter Harrison są zdania, że cierpienie zwierząt nie stanowi problemu dla teodycei, ponieważ zwierzęta doznają bólu jedynie w niewielkim stopniu lub nawet wcale. ${ }^{5}$ Nie zgadza się z tym Robert Wennberg. ${ }^{6}$ Hick twierdzi zaś:

[...] podstawowym problemem jest, czy zdarzenia zachodzące w przyrodzie, które nie dotykają ludzkości bezpośrednio, na przykład zabijanie jednych zwierząt przez inne, aby zaspokoić głód, obumieranie i rozkład roślin lub śmierć gwiazd, należy uważać za przejawy zła. Czy zło należy definiować wyłącznie w odniesieniu do działań i doświadczeń ludzkich, przez co zdarzenia przyrodnicze, niezwiązane z aktywnością człowieka, nie stanowiłyby problemu dla teodycei? Czy może zakres problemu należy roz-

\footnotetext{
${ }^{3}$ William H. Willmon, Sighing for Eden: Sin, Evil, and the Christian Faith, Abingdon, Nashville, Tennessee 1985, s. 34.

${ }^{4}$ Robert E.D. Clark, The Universe: Plan or Accident?, Paternoster Press, London 1961, s. 206.

${ }^{5}$ Por. Clark, The Universe...; Peter Harrison, „Theodicy and Animal Pain”, Philosophy 1989, vol. 64 , no. 247 , s. $79-92$.

${ }^{6}$ Por. Robert Wennberg, „Animal Suffering and the Problem of Evil”, Christian Scholar's Review 1991, vol. 21, no. 2, s. 120-140.
} 
szerzyć również na wszystkie istoty odczuwające bądź na same kręgowce lub jedynie ssaki wyższe? ${ }^{7}$

Zajmuje on w tej sprawie (przyjęte też $\mathrm{w}$ niniejszym artykule) stanowisko umiarkowane, zgodnie z którym

[...] cykl organiczny w nieodczuwającej części świata przyrody nie stanowi problemu dla teodycei, ale gdziekolwiek istnieje ból, a wszystko wskazuje na to, że doznają go nawet zwierzęta znajdujące się na niskich poziomach organizacji życia, jest to już prima facie problem wymagający rozwiązania. $\mathrm{W}$ świetle tego poglądu przejawami zła naturalnego są niespowodowane przez człowieka, niepożądane doświadczenia istot odczuwających — ludzi lub zwierząt. ${ }^{8}$

Hick objaśnia dwa główne typy teodycei, augustiańską i ireneuszową, oferujące przeciwstawne wyjaśnienia pochodzenia i celu zła naturalnego. Augustyn (354-432 n.e.), biskup Hippony, uważał, że zło bierze się z nadużywania wolności, z niewłaściwych wyborów dokonywanych przez racjonalne i obdarzone wolną wolą istoty — ludzi bądź aniołów. Wskutek ich grzechu stworzony przez Boga dobry i doskonały świat uległ zepsuciu. Zupełnie inną teodyceę przypisuje się Ireneuszowi (130?-202? n.e.), biskupowi Lyonu. Według niego Bóg stworzył świat, w którym od początku istniało zło naturalne. Świat ten miał być ,środowiskiem umożliwiającym rozwój człowieka ku doskonałości jako wypełnienia dobrego, wyznaczonego mu przez Boga celu". ${ }^{9} \mathrm{~W}$ tej perspektywie ani człowiek, ani świat nigdy nie znajdowały się w rajskim stanie, o jakim mówi teodycea augustiańska. Teodycea ireneuszowa nie była ujęciem dominującym w chrześcijaństwie zachodnim, ale jej założenia, w takiej czy innej formie, były i są przyjmowane przez znaczną liczbę ludzi.

W tradycji augustiańskiej przyczyną zła naturalnego był grzech wolnych, racjonalnych istot. Z poglądem tym identyfikuje się większość kreacjonistów młodej Ziemi, którzy wierzą, że zło naturalne jest rzeczywiste, że jest ono skutkiem upadku Adama i Ewy oraz późniejszego sądu Bożego nad nimi i całym stworzeniem. Według nich nie dawniej niż 10000 lat temu Bóg stworzył doskonały

\footnotetext{
${ }^{7}$ Hick, Evil..., s. 18.

${ }^{8}$ Hick, Evil..., s. 19.

${ }^{9}$ Hick, Evil..., s. 221.
} 
świat, w którym nie istniało zło moralne ani naturalne. ${ }^{10}$ Człowiek i przynajmniej zwierzęta $\mathrm{z}$ wyższych poziomów organizacji zostały stworzone jako istoty nieśmiertelne, niepodatne na choroby i niestarzejące się. Drapieżniki nie istniały. Wszystkie zwierzęta były roślinożerne. Ewolucja - a przynajmniej makroewolucja — nie stanowiła jednego z Boskich mechanizmów stwórczych. Druga zasada termodynamiki - zgodnie z którą wszystko dąży do stanu coraz większego nieuporządkowania - albo nie obowiązywała, albo Bóg nieustannie neutralizował ją swoją mocą podtrzymującą lub organizującą. W tym świecie pojawił się grzech moralny - dobrowolne odwrócenie się od Boga - a zaraz po nim zło naturalne. Całe stworzenie uległo zepsuciu. Przyjmuje się, że pasożyty, drapieżniki i organizmy chorobotwórcze pojawiły się dopiero po upadku w wyniku procesów mikroewolucyjnych. Stworzenia zaczęły się starzeć i umierać. Później doszło do kolejnego sądu Bożego — Bóg zesłał potop, który zapoczątkował ruchy skorupy ziemskiej, a w konsekwencji trzęsienia ziemi, erupcje wulkanów, epoki lodowcowe, masowe wymieranie (na co wskazuje zapis kopalny) oraz inne przejawy zła naturalnego. Krótko mówiąc, zło naturalne istnieje z powodu grzechu człowieka.

Inni chrześcijanie ${ }^{11}$ są przekonani, że Ziemia jest znacznie starsza niż dopuszczają kreacjoniści młodej Ziemi oraz że zapis kopalny świadczy o istnieniu śmierci i cierpienia na długo przed upadkiem Adama i Ewy. Nie chcąc jednak uznać, że te zdarzenia były zamierzoną częścią Boskiego stworzenia, sugerują oni, że to dawne zło naturalne było skutkiem upadku aniołów, który miał miejsce długo przed stworzeniem Adama i Ewy. Szatan, strącony na Ziemię wraz z innymi aniołami, zniszczył doskonałe dzieło Boże, przez co pojawiły się trzęsienia ziemi, wulkany, choroby, drapieżnictwo i śmierć. Upadek Adama i Ewy - wydarzenie, w którym dokonało się zerwanie związku człowieka z Bogiem, a więc i z Boskim stworzeniem - wywołał kolejne zło, w tym śmierć ludzi i dalsze zepsucie świata przyrody. Ta teodycea pozostawia miejsce dla procesów ewolucyjnych, nie ma jednak jednomyślności co do tego, w jakim stopniu mogły zachodzić przypadki „dobrej śmierci”. Lewis spekuluje, że drapieżnictwo

\footnotetext{
${ }^{10}$ Por. Henry M. Morris and Martin E. Clark, The Bible Has the Answer, rev. and expand. ed., Creation-Life Publishers, El Cajon, California 1987.

${ }^{11}$ Por. Lewis, Problem cierpienia...; Wennberg, „Animal Suffering...”.
} 
oraz duża płodność, która je kompensuje, to skutki wypaczenia pierwotnego Boskiego projektu przez Szatana. ${ }^{12}$

Wszystkie odmiany teodycei augustiańskiej zakładają niewinność Boga, a winą za pojawienie się zła naturalnego obarczają Jego stworzenia. Hick krytykuje teodyceę augustiańską, gdyż nie potrafi sobie wyobrazić, że zło mogło powstać „ex nihilo” i mieć źródło w „zamieszkujących całkowicie dobry świat, absolutnie dobrych istotach, które dopuściły się grzechu". ${ }^{13}$

Hick opowiada się za teodyceą ireneuszową. W jej świetle to Bóg ponosi ostateczną odpowiedzialność za zło naturalne. Człowiek, który jako twór ewolucji był niedoskonały i niedojrzały, dotarł w swoim rozwoju do punktu, w którym mógł już utworzyć wspólnotę z Bogiem i uświadomić sobie Jego obecność. Jednak Bóg nie mógł „wymusić” następnego etapu swojego planu dla człowieka powołania do istnienia dzieci Bożych, istot, które z własnej woli wybiorą miłość do Boga i rozwój ukierunkowany wiedzą o Nim. Przejście do tego drugiego etapu wymagało umieszczenia ludzi w niejednoznacznym świecie, podobnym do tego, w jakim żyjemy obecnie.

Hick argumentuje, że gdyby obecność Boga była jednoznacznie dostrzegalna w świecie, to człowiek nie mógłby w pełni swobodnie wybrać drogi ku Bogu, gdyż byłby przez Niego przytłoczony. Dlatego Bóg stworzył niejednoznaczny świat - świat zawierający ślady Jego istnienia, ale zarazem taki, który dopuszcza przekonanie o Jego nieobecności. Człowiek został umieszczony w tym świecie w taki sposób, by zachował - jak nazywa to Hick — „poznawczy dystans" wobec Boga. ${ }^{14}$ Był to świat pełny zarówno dobra, jak i rzeczywistego zła oraz wyzwań. Hick, posługując się określeniem Johna Keatsa, opisuje ten świat jako ,padół kształtowania duszy”. ${ }^{15}$ Tylko w takim świecie, poprzez długi proces dobrych i złych doświadczeń będących udziałem żyjących w nim stworzeń, ludzie mogli swobodnie wybrać miłość do Boga i rozwijać taką dobroć, jaką On uznaje za wartościową.

\footnotetext{
${ }^{12}$ Por. Lewis, Problem cierpienia....

${ }^{13}$ Hick, Evil..., s. 286.

${ }^{14}$ Por. Hick, Evil..., s. 317

${ }^{15}$ Por. Hıск, Evil..., s. 289.
} 
Według Hicka upadek był niemal nieuchronny, gdy człowiek, walcząc o przetrwanie w nieprzyjaznym świecie i będąc oddalonym od Boga, doszedł do przekonania, że Boga nie ma, a istnieje tylko świat przyrody. Uzasadnienie stworzenia świata, w którym istnieje zło, ma charakter eschatologiczny — „nieskończone przyszłe dobro ukaże wartość całego bólu, mozołu i okrucieństwa, jakich doświadczamy, zdążając do celu". ${ }^{16}$

Aby wyjaśnić pochodzenie zła naturalnego, teodycea augustiańska powraca w przeszłość do doskonałego stworzenia i nadużycia wolnej woli przez stworzone przez Boga istoty. Teodycea ireneuszowa zaś, starając się uzasadnić stworzenie świata, w którym istnieje zło, szuka rozwiązania w przyszłości. A co mówią o tym naukowe badania świata przyrody? Czy teorie naukowe mogą rzucić nieco światła na zdarzenia, które - w oczach chrześcijanina - mają przyczynę moralną i nadnaturalną podstawę? Na pierwszy rzut oka nie wydaje się to prawdopodobne, ponieważ nauka przyjmuje, że świat przyrody ma charakter pozamoralny. Co więcej, jednym z celów nauki jest wyjaśnienie materialnego Wszechświata za pomocą przyczyn czysto fizycznych i materialnych, bez powoływania się na przyczyny nadnaturalne. Na przykład z punktu widzenia nauki śmierć nie jest traktowana jako dobra lub zła bądź jako konsekwencja grzechu — jest po prostu ustaniem życia. Śmierć biologiczna może być niekiedy nazwana dobrą, lecz tylko w tym sensie, że ułatwia funkcjonowanie ekosystemu, umożliwiając przepływ energii przez sieci pokarmowe lub powrót do obiegu składników pokarmowych przetworzonych przez organizmy rozkładające materię organiczną. Może być tak, że nie każda śmierć jest konsekwencją grzechu. Niezależnie od tego, w jakim stopniu śmierć stanowi element dobrego Boskiego stworzenia, pełniejsze zrozumienie naszego świata wymaga naukowych teorii jej pochodzenia i funkcjonowania.

\section{Naukowe wyjaśnienia pochodzenia i celu zla naturalnego}

Wszelkie naukowe wyjaśnienia pochodzenia „zła naturalnego” odwołują się do procesów geologicznych lub biologicznych zachodzących w zgodzie z prawami przyrody. Na przykład trzęsienia ziemi i erupcje wulkanów spowodowane

\footnotetext{
${ }^{16}$ Hick, Evil..., s. 376.
} 
są przemieszczaniem się, zderzaniem i subdukcją płyt skorupy ziemskiej, tak jak ujmuje to teoria płyt tektonicznych. Procesy te postrzegane są jako naturalny skutek formowania się naszej planety. Podobnie jest w przypadku huraganów, tornad, powodzi, suszy i burz z piorunami, które są zjawiskami meteorologicznymi. Choć nie są one ściśle przewidywalne, to przynajmniej dość dobrze je rozumiemy - są efektem działania praw rządzących dyssypacją energii cieplnej i ruchem mas powietrza na kulistej planecie. Zgodnie $\mathrm{z}$ wiedzą biologiczną wiele pasożytów uważa się za ewolucyjnie przekształcone, strukturalnie uproszczone (zdegenerowane) formy organizmów, które pierwotnie prowadziły niezależny tryb życia. ${ }^{17}$ Wielu biologów uznaje, że wirusy to fragmenty DNA wyodrębnione kiedyś z komórek swoich dzisiejszych żywicieli. ${ }^{18}$ Pojawienie się licznych szkodników, w tym różnych kręgowców, chorobotwórczych mikrobów i insektów, przypisywane jest działalności ludzi, odpowiedzialnych za roznoszenie tych organizmów po całym świecie. W rezultacie niektóre $\mathrm{z}$ tych organizmów docierają do lokalizacji sprzyjających ich proliferacji — do miejsc, w których bądź nie mają one naturalnych wrogów, bądź znajdują nowych żywicieli, którzy nie wykształcili odporności na ich działanie. ${ }^{19}$ Jak dobrze wiadomo, wystawienie na działanie chemicznych mutagenów lub szkodliwego promieniowania przyczynia się do zachorowań na pewne postaci raka oraz wystąpienia wad wrodzonych.

W ramach wszystkich tych naukowych wyjaśnień pochodzenia ,zła naturalnego" uznaje się po prostu, że nasz świat funkcjonuje w zgodzie z prawami przyrody i że cierpienie, ból i śmierć są nieuchronnymi konsekwencjami życia w takim świecie. Na Ziemi wciąż zachodzi aktywność geologiczna, więc związane z nią niszczycielskie zdarzenia będą następowały nie inaczej niż to było do tej pory. To samo dotyczy poważnych zaburzeń meteorologicznych. Czasem ucierpią na tym ludzie i inne organizmy. Ewolucja nadal będzie tworzyć pasożyty, patogeny i drapieżniki, a organizmy narażone na ich ataki będą wykształcać

\footnotetext{
${ }^{17}$ Por. Peter H. Raven and George B. Johnson, Biology, 3rd ed., Mosby-Year Book, Inc., St. Louis, Missouri 1992.

${ }^{18}$ Por. Raven and Johnson, Biology....

${ }^{19}$ Por. Gail L. Schumann, Plant Diseases: Their Biology and Social Impact, APS Press, St. Paul, Minnesota 1991.
} 
mechanizmy obronne. Teorie naukowe wyjaśniają pochodzenie lub cel tych zdarzeń jedynie w taki sposób, że zdarzenia te stanowią nieodłączną część naszego świata. Czy zagadkę „zła”, jakim jest śmierć, można wyjaśnić podobnie? Wszak organizmy, którym uda się ustrzec przed wypadkami, chorobami lub drapieżnikami, i tak w końcu umierają. Starzeją się, degenerują i w końcu uchodzi z nich życie. Dlaczego dobór naturalny nie miałby faworyzować nieśmiertelności? Co o procesie starzenia się i śmierci mówi nauka?

Omówienie problemu starzenia się i śmierci ograniczę w tym artykule do dwóch zagadnień. Po pierwsze, rozważę przypadek śmierci organizmów wielokomórkowych, ponieważ, co ciekawe, nie wszystkie organizmy umierają. Jednokomórkowe prokarionty rozmnażają się przez podział. Każda nowa komórka dokonuje następnego podziału. Nieskończona replikacja komórkowa (nieśmiertelność) jest możliwa. ${ }^{20}$ Pewne jednokomórkowe protisty również rozmnażają się $\mathrm{w}$ ten sposób. Niektóre wielokomórkowe rośliny ${ }^{21}$ i grzyby ${ }^{22}$ potencjalnie mogą istnieć jako długowieczne klony, co rozmywałoby rozróżnienie na życie i śmierć organizmu. Po drugie, omówię przypadek kręgowców iteroparycznych (rozmnażających się więcej niż raz w dorosłym życiu). Ta grupa organizmów, obejmująca większość ssaków i ptaków, ma największe znaczenie teologiczne, ponieważ na gruncie teodycei kwestia cierpienia zwierząt najczęściej analizowana jest właśnie w odniesieniu do nich.

Teorie wyjaśniające ewolucję śmierci można podzielić na dwa typy: adaptacyjne i nieadaptacyjne. ${ }^{23}$ Teorie adaptacyjne przyjmują wspólną ideę, że starzenie się i śmierć mają jakąś pozytywną wartość, dają przewagę selekcyjną, zwiększają przystosowanie czy też zdolność organizmów do adaptacji. Jednym z możliwych korzystnych aspektów skończonej długości życia jest to, że

\footnotetext{
${ }^{20}$ Por. Robert Arking, Biology of Aging: Observations and Principles, Prentice-Hall, Inc., Englewood Cliffs, New Jersey 1991.

${ }^{21}$ Por. Hudson T. Hartmann, Dale E. Kester, and Fred T. Davies, Plant Propagation: Principles and Practices, 5th ed., Prentice-Hall, Inc., Englewood Cliffs, New Jersey 1990. 383.

${ }^{22}$ Por. Clive M. Brasier, „A Champion Thallus”, Nature 1992, vol. 356, no. 6368, s. $382-$

${ }^{23}$ Por. Thomas B.L. KIRKwood, „Comparative and Evolutionary Aspects of Longevity”, w: Caleb E. Finch and Edward L. Schneider (eds.), Handbook of the Biology of Aging, 2nd ed., The Handbooks of Ageing, Van Nostrand Reinhold Co., New York 1985, s. 27-44.
} 
w świecie z ograniczonymi zasobami śmierć jest konieczna do eliminacji starych osobników, dzięki czemu zasoby te będą dostępne dla ich potomstwa. Starzenie się i śmierć gwarantują także szybszą wymianę pokoleń (i genotypów), co umożliwia uzyskanie większej genetycznej zdolności adaptacji (ewolucję) do zmiennego środowiska. Teorie adaptacyjne postrzegają je więc jako „korzystne lub wręcz niezbędne do nałożenia skończonej granicy na życie osobnicze". ${ }^{24}$ Przeciwko teoriom adaptacyjnym przemawiają jednak różne grupy świadectw empirycznych. Słabą stroną argumentu z ,przestrzeni życiowej” jest fakt, że w przypadku żyjących na swobodzie populacji rzadko obserwuje się wyraźne oznaki starzenia. Do przypadkowej śmierci dochodzi tak często, że „nie tylko nie ma potrzeby istnienia jakiegoś szczególnego mechanizmu przerywania życia, ale nie ma nawet okazji, by mógł on wyewoluować". ${ }^{25}$ Ponadto, mając dwa genotypy różniące się jedynie tym, że jeden z nich posiada mechanizm przerywania życia w określonym wieku, trudno ustalić, dlaczego genotyp, który sam się eksterminuje, miałby mieć lepsze przystosowanie reprodukcyjne od drugiego genotypu. Ustalenie tego wymagałoby zaobserwowania, ,że selekcja działająca na korzyść gatunku lub grupy jest efektywniejsza niż selekcja osobników w obrębie grupy, które zyskują przewagę reprodukcyjną dzięki dłuższemu życiu". ${ }^{26}$ Jednak rzadko kiedy tak właśnie jest.

Ze względu na świadectwa przemawiające przeciwko teoriom adaptacyjnym większą popularnością cieszą się teorie nieadaptacyjne, zgodnie z którymi starzenie się jest szkodliwe dla wywołującego je genotypu. ${ }^{27}$ Teorie te muszą tłumaczyć ewolucję starzenia się w sposób bardziej pośredni, sugerując, że (1) siła doboru naturalnego słabnie wraz z wiekiem, ponieważ skumulowane skutki przypadkowej śmiertelności stopniowo redukują liczbę osobników osiągających coraz starszy wiek, lub że (2) śmierć stanowi produkt uboczny innych, przystosowawczych cech. Zasugerowano na przykład, że starzenie się ma związek z genami plejotropowymi (mającymi więcej niż jeden efekt fenotypowy), które są korzystne na wczesnych etapach życia (i podlegają pozytywnej selekcji z powo-

\footnotetext{
${ }^{24}$ KIRKWOOD, „Comparative and Evolutionary...”, s. 36.

${ }^{25}$ KIrKWOoD, „Comparative and Evolutionary...”, s. 37.

${ }^{26}$ KirKwood, „Comparative and Evolutionary...”, s. 37.

${ }^{27}$ Por. Kirkwood, „Comparative and Evolutionary...”.
} 
du dużej liczby młodych, rozmnażających się osobników), lecz niekorzystne w starszym wieku (nie podlegają jednak negatywnej selekcji, ponieważ przypadkowa śmiertelność sprawia, że istnieje niewiele starych osobników). Nad selekcją eliminującą geny, których szkodliwe działanie ujawnia się w późnym wieku, może więc przeważać selekcja faworyzująca ich korzystne działanie na wczesnych etapach życia. Starzenie się i śmierć byłyby ewolucyjnym produktem ubocznym selekcji przystosowawczych własności takich genów.

Na miejscu będzie tu omówienie teorii ciała jednorazowego użytku. Zgodnie $\mathrm{z}$ tą teorią ${ }^{28}$ można uznać, że organizmy wielokomórkowe składają się z linii płciowej i somatycznej. Linia płciowa, reprezentowana przez komórki rozrodcze, jest potencjalnie nieśmiertelna. Ciało lub komórki somatyczne (komórki ciała) biorą się z komórek rozrodczych i podlegają starzeniu się i śmierci. Teoria ciała jednorazowego użytku głosi, że większe przystosowanie reprodukcyjne uzyskiwane jest przez przydzielenie linii somatycznej mniejszej ilości energii niż potrzebowałaby ona do nieskończonego życia. Komórki somatyczne (a w rezultacie organizm) starzeją się na skutek skumulowanego wpływu różnorodnych losowych, szkodliwych zdarzeń i procesów. Uważa się, że te procesy zachodzą w stałym tempie, lecz komórkowe mechanizmy naprawcze nie są stuprocentowo skuteczne. W konsekwencji ilość energii potrzebnej do naprawy stale nagromadzających się uszkodzeń oraz utrzymania ciała przy życiu wzrasta wraz z wiekiem. Ze względu na prawdopodobieństwo przypadkowej śmierci żadne ciało nie może istnieć bez końca. Wraz z momentem ostatecznej i nieuchronnej

${ }^{28}$ Por. KIRKwood, „Comparative and Evolutionary...”; ARKING, Biology of Aging....

(Przyp. tłum.) Teoria ciała jednorazowego użytku została przedstawiona po raz pierwszy w artykule: Thomas B.L. KirKwood, „Evolution of Ageing”, Nature 1977, vol. 270, no. 5635, s. 301-304. Omówienie pewnych filozoficznych konsekwencji tej teorii można znaleźć w artykułach: Thomas B.L. KirKwood and Michael R. Rose, „Evolution of Senescence: Late Survival Sacrificed for Reproduction", Philosophical Transactions of the Royal Society B: Biological Sciences 1991, vol. 332, no. 1262, s. 15-24; Thomas B.L. KIRKwood, „The Origins of Human Ageing”, Philosophical Transactions of the Royal Society B: Biological Sciences 1997, vol. 352, no. 1363, s. $1765-1772$.

Popularne omówienie teorii ciała jednorazowego użytku w języku polskim czytelnik znajdzie w pracach: Thomas B.L. KIRKwood, Czas naszego życia. Co wiemy o starzeniu się czlowieka, przeł. Monika Kowaleczko-Szumowska, Wydawnictwo Charaktery, Kielce 2005, zwł. s. 83100; Dariusz Bugalski, „Skromni nosiciele genów (wywiad z Thomasem Kirkwoodem)”, Charaktery 2006, nr 1 (106), s. 52-54. 
śmierci wszystkie zasoby zainwestowane w utrzymanie ciała zostają utracone. Dzięki wydatkowaniu mniejszej ilości energii na utrzymanie ciała dodatkowa energia może zostać wykorzystana do zwiększenia aktywności reprodukcyjnej. Gdy koszt energetyczny naprawy ciała zaczyna przeważać nad kosztem energetycznym reprodukcji, to wedle teorii ewolucji aktywność naprawcza starzejącego się organizmu słabnie, zaczyna się on szybciej starzeć i w końcu umiera. Teoria ciała jednorazowego użytku wiąże się ze wspomnianą wcześniej koncepcją genów plejotropowych. Jeśli takie geny decydują o stopniu, w jakim działają procesy utrzymywania ciała przy życiu, to korzystnym skutkiem mniejszej siły działania takich procesów na wczesnych etapach życia jest zwiększona aktywność reprodukcyjna, natomiast skutkiem niekorzystnym w starszym wieku wcześniejsze osiąganie go. Tak więc pochodzenie oraz cel starzenia się i śmierci, podobnie jak innych przejawów zła na tym świecie, mogą mieć wyjaśnienie naturalistyczne.

\section{Teodycea augustiańska — dwa trudne pytania}

W tej części moim założeniem roboczym jest teza, że prawda została objawiona w Biblii i osiągalna jest na podstawie naukowych badań stworzonego świata. Odrzucenie któregoś z członów tej koniunkcji i przyjęcie tylko jednego nieuchronnie prowadzi do konfliktu i nieporozumien.

Podstawowe założenie kreacjonizmu młodej Ziemi, czyli całkowite odrzucenie naukowych (i biblijnych) świadectw starego wieku Ziemi, jest przejawem biblicyzmu i dlatego narażone jest na ostrą krytykę. Świadectwa przemawiające za kilkumiliardowym wiekiem Ziemi są mocne, a odgórne odrzucanie tej możliwości zakrawa na arogancję, skoro przecież istnieją inne zasadne interpretacje Biblii, które - w tym zakresie - znacznie łagodzą napięcia między nauką a wiarą. ${ }^{29}$ Przyjąwszy, że Ziemia jest stara, nie ma dobrych powodów, by wszelkie przejawy zła naturalnego przypisywać grzechowi pierwszych ludzi. Odrzucenie kreacjonizmu młodej Ziemi nie jest jednak równoznaczne z odrzuceniem teodycei augustiańskiej.

\footnotetext{
${ }^{29}$ Por. Henri Blocher, In The Beginning: The Opening Chapters of Genesis, InterVarsity Press, Downers Grove, Illinois 1984.
} 
Teodycea ireneuszowa popełnia być może błąd całkowicie przeciwny, skłaniając do powątpiewania w prawdziwość biblijnego objawienia. ${ }^{30} \mathrm{~W}$ myśl poglądów Hicka pierwszych ludzi dzieli od Boga większy dystans poznawczy niż można to zaakceptować w świetle tekstu Biblii. Upadek staje się praktycznie nieuchronny, a jako taki — niemal zrozumiały. Jego potworność, jak również różnica między dobrem a złem, jest zminimalizowana. Wreszcie, upatrywanie w Bogu przyczyny sprowadzenia zła naturalnego na świat nie pozwala nam, jak stwierdził Wennberg, „utrzymać zasady, że Bóg nigdy bezpośrednio nie pragnie lub nie stwarza zła; posługuje się on złem stworzonym przez innych, wyprowadza z niego dobro, lecz sam nie powołuje do istnienia zła, które wykorzystuje, by osiągnąc swoje dobre cele". ${ }^{31}$

W moim przekonaniu najwiarygodniejsza teodycea to taka, która przyjmuje augustiańską koncepcję, że to upadek aniołów odpowiada za pojawienie się zła naturalnego na świecie i zepsucie pierwotnie doskonałego stworzenia. Pogląd ten zachowuje niewinność Boga, zło przypisuje nadużyciu wolnej woli, dopuszcza możliwość powstania Ziemi miliardy lat temu i uznaje, że cierpienie i śmierć istniały na długo przed grzechem Adama i Ewy. Pozostają jednak poważne pytania. Na przykład, dlaczego Bóg pozwolił Szatanowi zniszczyć swój świat? Kwestią sporną są też Boskie mechanizmy stwórcze. Czy Bóg posłużył się mechanizmami ewolucyjnymi, czy też stwarzał z niczego? Czy teodycea augustiańska może pomóc w udzieleniu odpowiedzi na te pytania?

Tradycyjna odpowiedź na pierwsze pytanie, jak w zarysie przedstawia to Alvin Plantinga, ${ }^{32}$ stanowi obronę wolnej woli. Zgodnie $\mathrm{z}$ tą odpowiedzią, jak podsumowuje Wennberg, ,jest możliwe, że posiadanie i korzystanie z wolnej woli, zarówno w przypadku ludzi, jak i aniołów, a także posłużenie się nią w ce-

\footnotetext{
${ }^{30}$ Por. John W. Wenham, The Enigma of Evil: Can We Believe in the Goodness of God?, 2nd rev. ed., Zondervan, Grand Rapids, Michigan 1985.

(Przyp. tłum.) Pierwsze wydanie tej książki nosiło tytuł: The Goodness of God, Zondervan, Grand Rapids, Michigan 1974.

${ }^{31}$ WennBerg, „Animal Suffering...”, s. 134.

${ }^{32}$ Por. Alvin Plantinga, God and Other Minds: A Study of the Rational Justification of Belief in God, Contemporary Philosophy, Cornell University Press, Ithaca, New York - London 1967.
} 
lu uczynienia więcej dobra niż zła (a Bóg z góry wiedział, że tak będzie), stanowi dobro tak wielkie, że przyćmiewa ono całe zło na świecie". ${ }^{33}$ Bóg mógł dopuścić do buntu aniołów ze względu na wartość, jaką ma dla Niego wolna wola.

Na pierwsze pytanie można też odpowiedzieć na gruncie teodycei kształtowania duszy, zgodnie ze wspomnianym wcześniej ujęciem Hicka. Jeżeli celem, dla którego Bóg stworzył ludzi, było powołanie do istnienia istot zdolnych do tego, by w sposób wolny wybierać poznanie Boga i miłość do Niego oraz zdolnych do przemieniania się na obraz Chrystusa, to ten rodzaj świata, w jakim żyjemy, jest najlepszym możliwym światem do podjęcia takiej decyzji oraz ukształtowania duszy. Bóg nie przejawia się w świecie w sposób przytłaczający i apodyktyczny. Istnieje zło naturalne powodujące ból, cierpienie i śmierć, ale występują też świadectwa Boskiej obecności — w pięknie, harmonii, dobroci i uporządkowaniu świata. W takim niejednoznacznym świecie oddajemy się i jesteśmy wierni czemuś w sposób wolny. Wennberg pisze:

W niejednoznacznym środowisku — takim, w którym istnieje dobro i zło, światłość i ciemność - nadzieje i pragnienia muszą odgrywać rolę w ostatecznym oddaniu się czemuś, a to dlatego, że nic nie jest pewne ponad wszelką wątpliwość. Tak więc dana osoba może zwrócić się w kierunku światłości i dobroci po części dlatego, że chce, aby to była prawda o Wszechświecie, aby istniał Bóg miłości i sprawiedliwości, który ostatecznie zatriumfuje nad wszelkimi siłami zła, śmierci i destrukcji. Wiara jest częściowym wyrazem tej nadziei. ${ }^{34}$

Niektórzy sugerują, że akt oddania się Bogu w takich właśnie warunkach ma dla Niego głęboką wartość i znaczenie. Zatem Bóg pozwolił upadłym aniołom zakłócić swoje doskonałe stworzenie, ponieważ taki niedoskonały świat jest najlepszym z możliwych rodzajów świata, w jakim upadli ludzie decyzją swojej wolnej woli mogą wybrać miłość i wierność, których pragnie Bóg. O konieczności przeznaczenia takiego rodzaju świata dla upadłej ludzkości przekonany jest również Lewis, według którego „próbując wykluczyć możliwość cierpienia, które stanowi konsekwencję porządku natury i istnienia wolnej woli — odkryjemy, że

\footnotetext{
${ }^{33}$ WenNBERG, „Animal Suffering...”, s. 136.

${ }^{34}$ Wennberg, ,Animal Suffering...”, s. 138.
} 
wykluczamy w ten sposób samo życie". ${ }^{35}$ Co jeśli Adam i Ewa nie zgrzeszyli? Lewis zastanawia się nad ich stanem biologicznym jako bezgrzesznych jeszcze istot, ich możliwym zadaniem odkupienia stworzenia zaburzonego przez upadłe anioły, a także nad biologicznymi konsekwencjami ich upadku. ${ }^{36}$ John Wenham spekuluje, że w świecie, w którym nie doszło do upadku, nawet trzęsienia ziemi mogą być uważane za coś dobrego (gdyż dzięki nim formują się góry), a krzywda

[...] dzieje się, gdy człowiek, nie mając kontaktu ze swoim Stwórcą, znajduje się w niewłaściwym miejscu w niewłaściwym czasie. Człowiek mający kontakt ze Stwórcą znajduje się we właściwym miejscu we właściwym czasie i cieszy się Boską ochroną. To dzięki temu Jezus mógł spać bezpiecznie podczas burzy. ${ }^{37}$

Co ta teodycea kształtowania duszy mówi o cierpieniu zwierząt — zwłaszcza zwierząt odczuwających, takich jak ssaki i ptaki? Wennberg rozważa rolę cierpienia zwierząt $w$ tworzeniu środowiska dla kształtowania duszy i analizuje, czy jest to „zgodne z wizją Boga, którego miłosierdzie rozciąga się na wszystkie Jego stworzenia". ${ }^{38}$ Niewątpliwie kształtowanie ludzkiej duszy nie powinno być postrzegane jako jedyny powód istnienia zwierząt. Mają one zasadniczą wartość dla Boga, gdyż stanowią część Jego stworzenia, które uznał za dobre.

Przejdźmy teraz do drugiego pytania - do jakiego stopnia, z punktu widzenia teodycei, która zło naturalne przypisuje upadłym aniołom, Bóg posłużył się ewolucją jako swoim mechanizmem stwórczym? Wiąże się z tym pytanie, jak bardzo upadek aniołów zepsuł Boskie stworzenie? Przy odpowiedzi na te pytania warto rozważyć dwa skrajne poglądy.

Zgodnie z jednym ze stanowisk Bóg nie posłużył się ewolucją jako swoim mechanizmem stwórczym. Fred Van Dyke i Stanley Rice ${ }^{39}$ argumentują, że

\footnotetext{
${ }^{35}$ Lewis, Problem cierpienia..., s. 37.

${ }^{36}$ Por. Lewis, Problem cierpienia....

${ }^{37}$ Wenham, The Enigma of Evil..., s. 196-197.

${ }^{38}$ WennBerg, ,Animal Suffering...”, s. 121.

${ }^{39}$ Por. Fred VAN Dyke, ,Theological Problems of Theistic Evolution”, Journal of the American Scientific Affiliation 1986, vol. 38, no. 1, s. 11-18; Stanley Rice, „On the Problem of Apparent Evil in the Natural World", Perspectives on Science and Christian Faith 1987, vol. 39, no. 3, s. $150-157$
} 
ewolucja jest ze swej natury procesem samolubnym, którego podstawą są niedostatki zasobów, rywalizacja i śmierć. Całe pokolenia organizmów żyją i umierają, powoli przystosowując się do zmiennego środowiska. Gdy jedne gatunki powstają, inne - wymierają. Osobniki troszczą się o swoje przetrwanie, nie zaś o dobro ekosystemu. Czy mechanizm polegający na samolubnej skuteczności może być jednym z Boskich mechanizmów stwórczych? Czy śmierć towarzysząca ewolucji może być dobra? Jeśli odpowiedzi na te pytania brzmią nie, to jak mogło wyglądać pierwotne stworzenie? Prawdopodobnie nie istniała śmierć, nie było pasożytów, mięsożerców, mutacji czy wad wrodzonych. Zwierzęta odczuwające były nieśmiertelne i zostały stworzone z niczego — być może w różnych okresach długiej historii Ziemi.

Upadek aniołów przyniósł wielkie zmiany. Pasożyty, patogeny, drapieżniki i śmierć wypaczyły Boski plan (być może za pośrednictwem kierowanego przez Szatana procesu ewolucji). Zachwianie równowagi przez upadłe anioły doprowadziło z biegiem czasu (o czym świadczy zapis kopalny) do wymierania różnych gatunków - przypuszczalnie nawet dinozaurów! Z omówionych już powodów Bóg dopuścił te zaburzenia i działał tak, by ze zła wyprowadzać dobro.

Czy taki rodzaj świata jest możliwy? Być może. Musimy zachować ostrożność, by nie przykładać do przeszłego świata miary wziętej ze świata, który istnieje obecnie. Czai się tu jednak niebezpieczeństwo, że zaczniemy postrzegać Boskie stworzenie jako tak zepsute przez złe anioły, że uznamy, iż ono samo też jest złe. Jest to odmiana dualizmu, która według Wesleya Granberga-Michaelsona przyczynia się do tego, że chrześcijanie nie troszczą się o środowisko. ${ }^{40}$

Z drugiej strony ewolucję można uznać za jeden z Boskich mechanizmów stwórczych. Rice sugeruje, że ewolucja stanowi przykład duchowej zasady, stosowanej przez Boga, by z nieszczęścia wyprowadzać błogosławieństwo. ${ }^{41} \mathrm{Geo-}$ rge Murphy twierdzi, iż „Biblia to właśnie pokazuje — że Bóg obraca śmierć

\footnotetext{
${ }^{40}$ Por. Wesley Granberg-Michaelson, Ecology and Life: Accepting Our Environmental Responsibility, Issues of Christian Conscience Series, Word Books, Waco, Texas 1988.

${ }^{41}$ Por. Stanley Rice, „Bringing Blessings Out of Adversity: God's Activity in the Natural World”, Perspectives on Science and Christian Faith 1989, vol. 41, no. 1, s. 2-9.
} 
w życie, chaos w byt i daje nadzieję w beznadziejnych sytuacjach". ${ }^{42}$ Być może nie powinniśmy wywodzić nauk moralnych z pozamoralnego stworzenia, lecz ze spisanego Słowa Bożego. ${ }^{43}$ Murphy i Loren Wilkinson wskazują, że śmierć związana z ewolucją naprawdę nie jest czymś złym. ${ }^{44} \mathrm{~W}$ świetle tego poglądu śmierć stanowiła część Boskiego dobrego stworzenia, element „harmonijnego wzorca wymiany, który został stworzony przez Boga i uznany przez Niego za dobry". "Ś Śmierć zaczęto uznawać za coś złego dopiero po upadku człowieka. Od tego momentu, z powodu zerwania związku człowieka z Bogiem, śmierć postrzegana była jako wróg, przestała być czymś dobrym. W rezultacie każda śmierć - przeszła (skamieniałości), teraźniejsza i przyszła — interpretowana jest jako przejaw zła. Autorzy ci sugerują, że zapis paleontologiczny i całe istniejące życie należy uznać za - odpowiednio - historię i wynik kierowanego przez Boga dobrego procesu ewolucji. Pozostają jednak pewne pytania. Czy nieszczęście pochodzi od Boga? Czy nierozważnie jest oczekiwać, że w stworzeniu dostrzeżemy coś odzwierciedlającego moralną naturę Boga? Różnica między dobrem a złem wydaje się rozmyta. Jakie zło spowodowały upadłe anioły?

Możliwe, że żaden $\mathrm{z}$ tych skrajnych poglądów nie jest prawdziwy. Być może Bóg, w ciągu długiej historii Ziemi, powoływał organizmy do istnienia poprzez jakąś kombinację procesów ewolucyjnych i aktów stwórczych ex nihilo. Może organizmy te umierały dobrą śmiercią, gdy dotarły do ustalonej granicy swojego życia. Może pasożyty, patogeny, drapieżniki, skrajny ból i wyniszczające skutki starzenia się są kierowanymi przez złe istoty ewolucyjnymi zaburzeniami tego stworzonego porządku. Czy niszczycielskie zdarzenia meteorologiczne i geologiczne także mogą być atakami Szatana na Boży świat? Ludzie, stworzeni na obraz Boga, umierali śmiercią duchową (i fizyczną?) z powodu grzechu - dobrowolnego odwrócenia się od Boga. W jak wielkim stopniu srogość naszej kary może zabarwiać nasz pogląd na ewentualną dobrą (bezgrzesz-

\footnotetext{
${ }^{42}$ George L. Murphy, „A Theological Argument for Evolution”, Journal of the American Scientific Affiliation 1986, vol. 38, no. 1, s. 23 [19-26].

${ }^{43}$ Por. Rice, „On the Problem of Apparent Evil...”.

${ }^{44}$ Por. Murphy, „A Theological Argument...”; Loren E. WiLkinson, „A Christian Ecology of Death: Biblical Imagery and the Ecologic Crisis”, Christian Scholar's Review 1976, vol. 5, no. 1, s. $319-338$.

${ }^{45}$ Wilkinson, „A Christian Ecology of Death...”, s. 323.
} 
ną) śmierć w pozostałej części stworzenia? Należy także pamiętać, że wiele przejawów zła w świecie przyrody sięga swymi korzeniami do moralnego zła w świecie człowieka.

Prawdopodobnie niepodważalne odpowiedzi na rozpatrywane tu pytania poznamy dopiero, gdy trafimy do Nieba. Należy jednak zauważyć, że definitywne odpowiedzi nie są konieczne do usunięcia pozornej sprzeczności logicznej w poglądzie, że wszechpotężny Bóg miłości stworzył świat, w którym istnieje realne zło. Są one konieczne jedynie do wykazania, że ostatecznie zło nie pochodzi od Boga i że ma On swój cel, pozwalając nadal mu istnieć.

\section{Scalenie teologicznych i naukowych poglądów na pochodzenie i cel zla naturalnego}

Gdzie, z perspektywy chrześcijan, występują punkty zbieżności i rozbieżności między teologicznymi i naukowymi wyjaśnieniami pochodzenia i celu cierpienia, bólu i śmierci? Ogólnie biorąc, teologia i nauka są ze sobą zgodne wówczas, gdy uznamy, że każda z tych dziedzin dostarcza jedynie częściowego spojrzenia na rzeczywistość. Rozbieżności powstają wtedy, gdy zamiast wyjaśnień teologicznych i naukowych proponowane są wyjaśnienia zabarwione biblicyzmem i scjentyzmem. W tym wypadku równowaga zawsze jest chwiejna, ale wydaje mi się, że w dzisiejszym klimacie naukowym, negującym duchowy wymiar rzeczywistości, ${ }^{46}$ szala przechyliła się zbyt mocno na niekorzyść teologii i należy to naprawić. Na przykład naukowa wiedza o przyczynach niszczycielskich zdarzeń geologicznych i meteorologicznych ogromnie się powiększyła, dzięki czemu można je wyjaśniać za pomocą znanych praw naukowych. Jednak prawa naukowe są opisami rzeczywistości, nie zaś przepisami. Opisanie, jak funkcjonuje Ziemia, to nie to samo, co ustalenie, jak Ziemia musi funkcjonować. Gdyby pochodzenie tych niszczycielskich zdarzeń naprawdę miało związek z aktywnością upadłych aniołów, to na Ziemi, na której nie zachodziłaby taka aktywność, nie byłoby trzęsień ziemi i wulkanów. Nauka nie może wykazać, że jakieś poszczególne powodzie, susze, burze lub trzęsienia ziemi, występujące w danym okresie historii, nie zostały spowodowane przez aktywność istot nad-

\footnotetext{
${ }^{46}$ Por. Granberg-Michaelson, Ecology and Life....
} 
naturalnych i że Bóg nie posłużył się nimi dla swoich celów. Zagadnienie to znajduje się poza domeną nauki.

Ewolucję często opisuje się jako losową oraz pozbawioną celu i niekierowaną. Są to twierdzenia nie tyle naukowe, ile wyrażające naturalistyczną filozofię niektórych naukowców. Naukowa teoria ewolucji stara się zrozumieć mechanizmy zmiany: na przykład, jak tasiemiec mógł wyewoluować z przodka prowadzącego niezależny tryb życia. W jakimkolwiek stopniu Bóg lub upadłe anioły posłużyły się procesami ewolucyjnymi, zawsze musiało mieć to jakiś cel. Z perspektywy nauki wytwory ewolucji (pandy, tasiemce czy lwy) są moralnie neutralne. Jeśli istniał jakiś nieprzyjazny zamysł, to tasiemce lub lwy można uważać za istoty złe, za wypaczenia Boskich zamiarów dla tych stworzeń.

Jeśli zwierzęta, poza ludźmi, zostały stworzone jako istoty śmiertelne, a ich śmierć stanowiła część dobrego projektu Boga, to takie modele jak teoria ciała jednorazowego użytku mogą nam pomóc zrozumieć, jak Bóg zrealizował plan nadania organizmom skończonej długości życia. Jeżeli jednak śmierć zwierząt jest rezultatem ataku Szatana, to takie teorie nie są wystarczające. Wiedza naukowa czy naukowe teorie — na żadnym poziomie — nie wykażą, że mechanizmy starzenia się zaistniały jako zła aberracja Bożego zamysłu. Z naukowego punktu widzenia ludzie są jedynie innym gatunkiem zwierząt. Można dowieść, że starzejemy się i umieramy $\mathrm{z}$ takich samych powodów, co zwierzęta. Mimo to Biblia, w popularnej interpretacji, wskazuje, że Adam i Ewa byli potencjalnie nieśmiertelni. Takie aspekty ludzkiego życia jak nasz wymiar duchowy, stworzenie na obraz Boga, wykraczają poza domenę nauki. W świetle scjentyzmu istoty duchowe i zmartwychwstanie ciała są niemożliwe. Biblia mówi jednak coś innego.

Chrześcijanie łatwo mogą zaakceptować naukowe rozumienie pochodzenia takich procesów fizycznych jak trzęsienia ziemi i burze, które niekiedy powodują ból, cierpienie i śmierć. Takie rozumienie jest użyteczne, ponieważ pozwala nam na uniknięcie i czasem na osłabienie siły tych niszczycielskich zdarzeń. Naukowe wyjaśnienie pochodzenia wirusów, pasożytów, bakterii chorobotwórczych oraz procesów powodujących starzenie się i śmierć także jest użyteczne, gdyż umożliwia nam walkę z tymi szkodliwymi czynnikami. Jeżeli jednak te fizyczne i biologiczne zdarzenia mają związek z upadkiem aniołów lub człowie- 
ka, to naukowe wyjaśnienia pochodzenia tych zdarzeń zawsze będą niekompletne. Jeśli te przejawy zła istnieją za przyzwoleniem Boga i dla jego celów, to nauka nigdy nie będzie w stanie wyjaśnić pełnego znaczenia tych zdarzeń.

Chrześcijański pogląd na świat musi opierać się tak na nauce, jak i na teologii. Chrześcijanie powinni zwracać się w stronę nauki po wyjaśnienia dotyczące funkcjonowania świata, lecz to teologia umożliwi im znalezienie ostatecznego sensu i celu.

Gary Emberger

\section{Theological and Scientific Explanations for the Origin and Purpose of Natural Evil}

\section{Summary}

Events such as earthquakes and crippling illnesses are often viewed as evils and raise troubling questions about God's goodness. While science does not recognize these events as evils, it does offer insights into their origins. Theodicy attempts to explain theologically how evil originated and for what purpose God allows it to exist. Adopting either Augustinian or Irenaean theodicy has important implications concerning the question of whether evolution could be one of God's creative mechanisms. Finally, recognizing that all truth is God's truth, Christians seek to develop a world view that includes both scientific and theological understanding of harmful natural events.

Keywords: natural evil, moral evil, free will, Augustinian theodicy, Irenaean theodicy, Christian God, Satan, evolutionary theory, disposable soma theory.

Słowa kluczowe: zło naturalne, zło moralne, wolna wola, teodycea augustiańska, teodycea ireneuszowa, Bóg chrześcijański, Szatan, teoria ewolucji, teoria ciała jednorazowego użytku. 